\title{
LAND USE TRANSFORMATION IN THAR DESERT: A CASE STUDY OF BARMER DISTRICT, RAJASTHAN
}

\author{
Balak Ram ${ }^{1}$ and J. S. Chauhan ${ }^{2}$ \\ ${ }^{1}$ Former Principal Scientist, Central Arid Zone Research Institute, Jodhpur, India \\ ${ }^{2}$ Chief Technical Officer, Central Arid Zone Research Institute, Jodhpur, India \\ Email:dr.brmayank@gmail.com
}

\begin{abstract}
Barmer, the western most district of Arid Rajasthan, has recently witnessed dynamic changes in land use; agriculture and irrigation, exploration of crude oil and natural gas, lignite and other minerals; and infrastructure developments. Using multifaceted historical data from 1960-61 and interpretation of LANDSAT 8 images of January, 2018 and Sentinel-2A imagery of February, 2017, major changes/developments in relation to physical environment as well as natural and human resources, are assessed and mapped. Drivers of such changes as well their positive and negative impacts are brought out and key challenges are highlighted towards development planning. Barmer district with $28387 \mathrm{Km}^{2}$ areas has its 78 percent area under agriculture which is mainly rainfed and supported on sand dunes and interdunal plains. Net and gross irrigated area is now 9.22 percent and 13.58 percent. Cumin, isabgol and castor are most promising cash crops. Since 1960-61 the net sown area has increased by 27.9 percent, net irrigated area by 27.5 times and gross irrigated area by 40.5 times. Total crop production has increased by 183.4 percent. Consequently, five blocks of the district are overexploited through groundwater and the state of groundwater development is 114.23 percent. Major developments are: exploration of minerals like lignite; crude oil and natural gas from Barmer-Sanchore Basin; Introduction of Narmada Canal for irrigation and drinking water in 83000 ha command area in Dhorimanna and Guda Malani tehsils, coming up of 9.0 MMTPA capacity HRRL Pachpadra Refinery; and development of Desert National park and Wildlife Sanctuary.
\end{abstract}

Key words: Land use, Irrigation, Cropping Pattern, Arid Zone, Lignite, Barmer- Sanchore Basin, Oil and Natural Gas, Narmada Canal

\section{Introduction}

Land use keeps changing with time through human intervention influenced by their needs and choices. In fragile hot arid zone of India, the land use system is highly delicate, less dependable and minimal livelihood supportive. However, in recent past enormous changes and developments in land use systems are taken place. Man has succeeded to create irrigation potential through sinking more wells and bringing canal irrigation; cultivation of cash crops, exploration of minerals and oil and gas and infrastructure development. Spread over an area of $28387 \mathrm{Km}^{2}$ and accommodating over 26 lac human and 54 lac livestock population, the development scenario of the district is enormously changed from 1990 onward. In view of such developments, the present study has been undertaken to study, assess and map these changes/developments in relation to physical environment as well as natural and human resources analysing multifaceted and historical dataset from 1960-61 to 2016-17. These include; land use, irrigation, cropping pattern, crop production; Narmada Canal Project, Desert National Park and Wildlife Sanctuary; Textile dyeing and printing industries and impact of industrial effluents; exploration of lignite as well as crude oil and natural gas from BarmerSanchore Basin; and coming up of HRRL Pachpadra Refinery. Major drivers of such changes and their impact on environment, natural resources and animate and inanimate life of this desert district, are discussed. The human and livestock population in the district has increased by 300.7 percent and 155 percent respectively since 1961 .

Net sown area and total cropped area are increased by 27.9 percent and 44.4 percent. Net irrigated area has increased 27.5 times i.e. from 9440 ha in 1960-61 to 259877 ha in 201617 and gross irrigated area by 40.5 times. Crop production has increased just 183.4 percent from 123849 tons to 350951 tons over this period. Major challenges of the region are fast degradation of ground water resources, declining productivity and dependency from rainfed agriculture, increasing man-induced land degradation, creation of mine spoil area and 
shrinkage, encroachment and degradation of pastures and other common lands. Strategies to address crucial challenges are suggested.

\section{Method and Materials}

Basic framework on climate and natural resources set up for this study, has been adopted from the natural and human resources survey report of CAZRI (1989), Land use/land cover report (CAZRI,1990), Wasteland Mapping (Balak Ram and Gheesa Lal,1999) and Wasteland Updation (Balak Ram, 2004). Trend in land use, cropping pattern and crop production from 1960-61 to 2016-16 had been worked out these reports and annual Statistical abstracts of Rajasthan. Various aspects of human resources are analysed from Census of India, 2011. Recent developments are synthesised from published and unpublished reports of CGWB (2013), Narmada Canal Project, Rajasthan (2017), CAIRN India (2018), RSMML and WAPCOS (2014), Management Plan of Desert National Park (Anon. 2017c), innovative farming system model (BAIF, 2012) and other departments. Based on these reports a map depicting such developments is prepared.

\section{RESULTS AND DISCUSSION}

\section{Location and Administrative setup}

Barmer the westernmost district of Rajasthan with a total geographical area of $28387 \mathrm{Km}^{2}$ extends from $70^{\circ} 05^{\prime} 06^{\prime \prime}$ to $72^{\circ} 50^{\prime} 55^{\prime \prime} \mathrm{E}$ longitudes and from $24^{\circ} 38^{\prime} 52^{\prime \prime}$ to $26^{\circ} 30^{\prime} 41^{\prime \prime} \mathrm{N}$ latitudes. It is bounded by Jaisalmer and Jodhpur districts towards north; Jalor district towards south; Jodhpur and Pali districts towards north east and Tharparkar district of Pakistan towards west (Fig.1). The district is divided into eight sub-divisions; 17 Development Blocks or Panchayat Samiti viz. Sheo, Barmer, Baytu, Chohtan, Dhorimanna, Sindhari, Siwana, Balotra, Dhanau, Patodi, Ramsar, Gadra Road, Gida, Samdari, Guda Malani, Sedva and Kalyanpur ( Anon. 2010, 2012); 14 tehsils with 2712 villages and 2 towns viz. Barmer and Balotra.

As per 2011 census the district has a population of 2603751 (1369022 males and 1234729 females) with a density of 92 persons $/ \mathrm{Km}^{2}$ and decennial growth of 32.52 percent. 93 percent population reside in rural areas while rest 7 percent in urban centres. Literacy rate is 57.49 percent. Scheduled caste and Scheduled Tribes population constitute 16.8 percent and 6.8 percent. Religion wise Hindus constitute 86.72 percent, Muslim 12.34 percent, Jain 1.31 percent and rest by other religious communities. Work participation rate is 46.2 percent. Out of total population main workers are 28.47 percent, marginal workers 17.71 percent and nonworking population 53.82 percent. Out of total workers cultivators are 62.7 percent, agricultural labourers 11.0 percent household industries 2.6 percent and others 23.7 percent respectively (Anon. 2014). The livestock population of the district as per 2012 livestock census is 5366732 with a density of 189 animals $/ \mathrm{km}^{2}$. Out of total animal population cattle constitute 14.69 percent, buffaloes 3.99 percent, sheep 26.16 percent, goat 53.97 percent, horse and ponies 0.05 percent mules and donkey 0.33 percent and camel 0.81 percent respectively. The total milk production in 2013-14 comes to 5960,000 MT which is an increase of 138.4 percent from 2001.

\section{Environment and Resources}

The climate of the district is extremely arid with a mean aridity index of 85 percent and standard deviation of $8.7 \mathrm{~mm}$. Extremes of temperatures, erratic and fitful rainfall, high dust storms during summer and frequent droughts mark climatic characters. May and June are the hottest months recording mean maximum temperatures of $41.9^{\circ} \mathrm{C}$ and $40.3^{\circ} \mathrm{C}$ respectively which may often cross $45^{\circ} \mathrm{C}$. During December and January, the mean minimum temperatures are lowest being in order of 10 to $12^{\circ} \mathrm{C}$ with lowest mean monthly temperatures recorded being $9.2^{\circ} \mathrm{C}$ and $7.5^{\circ} \mathrm{C}$ respectively. Mean annual rainfall of the district (1901-1998 average) is $268.35 \mathrm{~mm}$ which varies from (NW) $209.7 \mathrm{~mm}$ at Sheo to $345.8 \mathrm{~mm}$ at Siwana occurring in 9.4 to 15.2 rainy days. The average annual rainfall from last 10 years (2009-2018) comes to $331.5 \mathrm{~mm}$ (Water Resources Dept. Raj.).

The district present a picture of vast sandy plain dotted with sand dunes and interdunes and at places rugged hills and saline depressions. The ephemeral Luni is the only river of this region which has its outlet in Rann of Kachchh. Soils of the district are dominantly coarse textured. Soil texture along the bank of river Luni ranging from loamy sand to clay loam; sandy plains with fine sand to loamy sand, $70-90 \mathrm{~cm}$ deep underlain by lime concretionary horizon; 
sand dunes and inter dunes with fine sandy, very deep and slightly calcareous soils. These soils have low available water holding capacity and low fertility status (CAZRI, 1989). Total water resources in the district as per 2010 estimation comes to $2444.3 \mathrm{Mm}^{3} /$ year. This includes surface water 351.2, imported water 1499.9 and dynamic ground water $592.9 \mathrm{Mm}^{3} /$ year (fresh 310.5 and saline 282.4). The total water requirement comes to $4827 \mathrm{Mm}^{3} /$ year (Beg and Ahmad, 2015). Net groundwater availability is $257.5135 \mathrm{MCM}$ and annual groundwater draft 294.1440 MCM. Stage of groundwater development thus comes to 114.22 percent (CGWB, 2013). Five blocks in the district viz. Baytu, Balotra, Siwana, Dhorimanna and Sheo are identified as overexploited.

Barmer district has achieved significant achievement in mineral exploration. Lignite is most important among them with an annual production of 7.54 million tons. Others are bentonite (171706 tons), gypsum (76275 tons), siliceous earth (12120 tons), fuller's earth (13096 tons) and selenite 1800 tons (Anon. 2016). Besides; granite, masonry stone, kankar/bajri and murram/gitti are too produced with an order of 206775, 1700705, 1431057 and 150000 tons respectively (Deptt. of Mines and Geology, Raj.). There are 1427 mineral based industries in the district. Total registered medium and small (MSME) units by the end of March, 2016 are 4168 giving employment to 26565 person which includes 2145 textile industries (other than handloom), 260 agro based, mineral based 371, service and repair 464 and wooden 199 (MSME, 2011 and Anon. 2017d, 2017e).

\section{Land use and Agriculture}

Barmer is a unique district of 'Thar Desert' which has 78 percent of its total area under agriculture which is dominantly rainfed and supported by sand dunes and inter dunal plains. As per agricultural statistics of 2016-17 (Anon. 2019), the net sown area in the district comes to 59.3 percent, current fallow 7.44 percent 2-5 years fallow 11.2 percent and culturable waste 6.25 percent respectively. Double cropped area comes to 7.88 percent, net irrigated area 9.22 percent and gross irrigated area 13.58 percent. Area under forest land is 1.18 percent, land put to non-agricultural uses 2.85 percent, barren and uncultivable land 4.42 percent and permanent pasture/grazing land 7.2 percent. Out of gross irrigated area, 243830 ha or 92.28 percent percent is served by wells and tube wells, 7.71 percent by Narmada canal system and 0.01 percent by other sources.

Limited choice of crops is one of the major constraints in arid agro-ecosystem. Bajra, guar and moth are dominant crops constituting 42.0 percent, 22.05 percent and 13.45 percent of the total cropped area in the district (Anon. 2019). Other important crops are cumin (7.29 percent), Isabgol (7.03 percent), moong (3.94 percent), castor (1.21 percent), wheat (0.93 percent) and mustard (0.76 percent). Besides; jowar, gram, groundnut, methi, taramira, fennel, pomegranate, onion and other vegetable and fodder crops are taken. Total production was 3.51 lac tons. Area and production of important crops for the year 2016-17 is shown in fig. 2 . The impact of rainfall on failure of rainfed crops is such that during the year 2018, crops in 44.4 percent area and in 2016 the crops in 67. 6 percent area was damaged due to severe drought/failure of monsoon.

\section{Narmada Canal Command Area}

$458 \mathrm{~km}$. long Narmada canal taken out from Sardar Sarovar Dam has been designed to provide irrigation as well as drinking water to Jalor and Barmer districts of Rajasthan with a gross command area (GCA) of 2.86 lakh ha and culturable command area of 2.46 lakh ha, was inaugurated on $24^{\text {th }}$ April, 2008. $74 \mathrm{~km}$ long Narmada main canal in Rajasthan with a distribution system of $1719 \mathrm{~km}$. of distributaries, minor, sub-minor and lift. In Barmer district it has 83000 ha culturable command area (4000 ha under flow and 79000 ha under lift) of Dhorimanna and Guda Malani tehsils. Thus 11 villages will be served with flow irrigation and 97 villages with lift (Swain et al. 2018). Besides 667 villages will be benefited with drinking water. There will be pressurized irrigation in lift area through micro irrigation system (MIS) with sprinkler and drip (nwm.gov.in/default/waterwiki/14.pdf).

\section{Lignite Exploration}

Lignite opencast mining in Barmer district started in 1994 from Giral mine field. Major lignite mine fields area located in Giral, Shivkar, Sonari, Kapurdi and Jalipa covering mining lease area of 11174 ha. The total production at present comes to 4771286 tons. Giral and Shivkar field covers 2655.7 ha; Sonari 1512.5 ha, Kapurdi 3223.51 ha and Jalipa 3782.31 ha 
respectively (BLMCL, 2014 and RSMML and WAPCOS, 2014). Lignite based two thermal power plants (Giral TPP 250 MW and Kapurdi TPP $108 \mathrm{MW}$ ) are also in operation to provide electric power to this industry.

Table 01: Land use changes (percent) in Barmer District, Rajasthan

\begin{tabular}{|l|l|l|l|l|l|l|l|}
\hline Land use category & $\mathbf{1 9 6 0 - 6 1}$ & $\mathbf{1 9 7 0 - 7 1}$ & $\mathbf{1 9 8 0 - 8 1}$ & $\mathbf{1 9 9 0 - 9 1}$ & $\mathbf{2 0 0 0 - 0 1}$ & $\mathbf{2 0 1 0 - 1 1}$ & $\mathbf{2 0 1 6 - 1 7}$ \\
\hline Forest & 0.43 & 0.44 & 0.50 & 0.89 & 1.01 & 1.14 & 1.18 \\
\hline Land put to non-agrl. uses & 2.66 & 1.73 & 2.33 & 2.59 & 2.61 & 2.62 & 2.85 \\
\hline Barren and uncultivable land & 5.18 & 5.60 & 4.82 & 4.51 & 4.38 & 4.39 & 4.42 \\
\hline Pasture/grazing land & 0.85 & 7.29 & 7.55 & 7.44 & 7.23 & 7.22 & 7.20 \\
\hline Misc. tree crops \& groves & 0.00 & 0.00 & 0.00 & 0.00 & 0.00 & 0.00 & 0.04 \\
\hline Culturable waste & 9.75 & 14.96 & 11.88 & 9.44 & 8.21 & 6.28 & 6.25 \\
\hline Other fallow land & 23.54 & 20.92 & 12.19 & 11.68 & 13.90 & 8.26 & 11.40 \\
\hline Current fallow & 9.12 & 4.17 & 7.75 & 7.70 & 7.38 & 6.47 & 7.44 \\
\hline Net area sown & 46.27 & 44.34 & 52.98 & 55.86 & 55.09 & 63.62 & 59.31 \\
\hline Total cropped area & 46.62 & 45.07 & 53.83 & 57.06 & 58.58 & 70.26 & 67.19 \\
\hline Area sown more than once & 0.15 & 0.51 & 1.64 & 1.21 & 3.49 & 6.64 & 7.88 \\
\hline Gross irrigated area & 0.33 & 0.46 & 1.38 & 1.50 & 5.34 & 9.03 & 13.58 \\
\hline Net irrigated area & 0.32 & 0.36 & 0.78 & 0.61 & 2.90 & 5.85 & 9.22 \\
\hline
\end{tabular}

Sources: Anon. (1992) Trend in land use statistics, Rajasthan and Statistical Abstracts

\section{Hydrocarbon Oil and Gas Exploration, Development and Production}

Initiated in 1999, the exploration, development and production of hydrocarbon crude oil in Barmer district were commenced from 2004 in Barmer Basin RJ-ON-90/1 Block by CAIRN Oil and Gas Division of Vedanta group. This basin was discovered in 2004 and production started in August 2009 in Mangala, 2012 in Bhagyam and 2013 in Aishwariya oil fields. The block with an area of $3111 \mathrm{~km}$ is spread mainly in Barmer and partly in Jalor districts. Mangala Processing Terminal (MPT) and Raageshwari gas terminal (RGT) are two terminals for processing hydrocarbons. MPT is producing on an average 175000 BOPD. RGT is producing up to 55 MMSCFD of natural gas (CAIRN, 2018). CAIRN has developed $700 \mathrm{~km}$ long and 24" crude oil pipeline (from MPT in Barmer to Bhogat in Gujarat) and $600 \mathrm{~km}$ long 8" gas pipeline from RGT to Bhogat, Dwarka. 38 oil and gas fields are discovered 783 oil wells are drilled which will able to produce 400000 BOPD and 750 MMSCFD of gas. In addition, multiple satellite fields are developed. The crude oil from these satellite oil fields can be directly spiked to export crude to oil pipeline. A total of 640.09 lac metric tons or 463.00 million barrels crude oil has been produced so far from 29.8.2009 to May 2018 (Kothari et al. 2015).

\section{HPCL Rajasthan Refinery, Pachpadra}

HPCL Rajasthan Refinery Limited is coming up near Pachpadra town with a capacity of 9.0 MMTPA (Million metric tons per annum) with an investment of 37230 crores. Rajasthan Govt. has provided 926 ha of land free of cost. It will be located in villages Sajiyali Roopji Kanthawar and Sambhara of Pachpadra tehsil. It will spread over 1780.75 ha for Refinery cum Petrochemical complex and marketing terminal and additional 167.42 ha is reserved for township and reservoir which will be $2.5 \mathrm{~km}$ from complex (EIL, 2018).

\section{Textile Dyeing and Printing Industries and its Environmental Impact}

Balotra town is famous for textile dyeing and printing industries and so called, 'Poplin City'. This industry is developed around Balotra, Jasol and Bithuja region. There are more than 5000 textiles dyeing and printing units in Balotra and environ. The effluents emanated from these units posed serious problem. Consequently, three CETP (Common Effluents Treatment Plant) are established to treat industrial effluents (EIL, 2018).

\section{Desert National Park Wildlife Sanctuary}

Out of total $3162 \mathrm{~km}^{2}$ area of Desert National Park Wildlife Sanctuary, $1400 \mathrm{Km}$ lies in Barmer district and $1762 \mathrm{Km}$ in Jaisalmer district. In Barmer district it occupies 31 complete villages and 22 partial villages of Sheo tehsil. Out of total area of DNP, 36.95 percent comprises revenue land, 42.6 percent private holdings and 20.45 percent Gochar land. Total area under forest is 1579.1019 ha which includes 263.7477 Protected Forest and 1315.3532 ha unclassified forest. (Anon. 2017c). Major objectives of this project are to develop desert ecosystem; protect rare, threatened and endangered elements of flora and fauna; increase population of Great Indian Bustard; and promote eco-development and eco-tourism. 


\section{Change in Land Use, Cropping Pattern and Crop Production}

Net sown area, double cropped area an irrigated area have shown significant increase in land use system over the period from 1960-61 to 2016-17 (Anon. 1992, 2017a, 2017b and 2019). Consequently, the area under long fallowing practices has declined. Details are given in table 2. Net sown area and total cropped area are increased by 27.9 percent and 44.4 percent. Net irrigated area has increased 27.5 times i.e. from 9440 ha in 1960-61 to 259877 ha in 2016-17 and gross irrigated area by 40.5 times (Anon. 2019). Crop production has increased just 183.4 percent from 123849 tons to 350951 tons over this period. In 1990-91 it was 308634 tons (Anon. 2018). Thus crop production has mainly increased from irrigated crops while in rainfed crops shown dormant trend. Surprisingly, the production of bajra has increased just by 2.28 percent. Cumin and isabgol proved most promising cash crops.

\section{IMPACTS OF CHANGES/DEVELOPMENT}

Prospective: Substantial increase in agricultural production particularly of irrigated cash crops like cumin, isabgol and castor; creation of pressurized irrigation potential over undulating sandy area through sprinkler and drip; increase in economy and revenue has enhanced the standard of living and purchasing power of households. Other impacts are employment generation; better improvement in mobility, accessibility and transport of goods, availability of better education and health facilities; landmark development in exploration of crude oil and natural gas as well as establishment of oil refinery; and exploration of minerals like lignite, bentonite and gypsum, will together bring revolution in regional economy.

Retrospective: Degradation of ground water resources has already turned hectares of irrigated double cropland into single crop/wasteland and in future this hazard is going to be more harmful. Unmanaged textile industrial effluents is continue to ruin irrigated cropland, harm irrigation wells and destroy native flora and fauna. Rainfed farming become less supportive to peasant's livelihood and hence their interest is gradually declining. Illegal, unscientific and unplanned mining activities disfigured the terrain, blocked the natural drainage system and created new wastelands. Shrinkage, encroachments and removal of trees and shrubs led to loss of grazing material and degradation/ reduction of pastures/grazing lands. Uncontrolled spread of Prosopis juliflora has supressed important native flora and hampering mobility of man and animal. Lack of proper planning and support led to ruin the salt industry of famous Pachpadra Salt basin.

\section{Conclusion}

Barmer district though has $3 / 4$ area under agriculture but most of it (82.17 percent) is rainfed which is highly risky, full of uncertainty with poor yield from less remunerative crops viz. bajra, moth bean and guar. Net and gross irrigated area are now 9.22 percent and 13.58 percent. Cumin, isabgol and castor are most promising cash crops. Since 1960-61 the net sown area has increased by 27.9 percent, net irrigated area by 27.5 times and gross irrigated area by 40.5 times. Total crop production has increased by 183.4 percent. Five blocks of the district are overexploited through groundwater and the state of groundwater development is 114.23 percent. Major developments are exploration of minerals like lignite; crude oil and natural gas from Barmer-Sanchore Basin; Introduction of Narmada Canal for irrigation and drinking water in 83000 ha command area in Dhorimanna and Guda Malani tehsils, coming up of 9.0 MMTPA capacities HRRL Pachpadra Refinery; and development of Desert National Park and Wildlife Sanctuary. Important strategies for development of the region are: to develop innovative integrated farming system based on livelihood model; increase water productivity; equitable exploitation, judicious use and proper management of water resources; scientific and environmental friendly exploitation of mineral resources; rehabilitation and development of degraded lands; effective management of industrial effluents; promote traditional skill and related enterprises; and create basket of opportunities for desert communities to generate income in their own setting.

\section{References}

1. Anon. (1992) Trend in Land use Statistics, Rajasthan. Directorate of Agriculture (Statistical Wing), Rajasthan, Jaipur, p. 342.

2. Anon. (2010) District Statistical Outline 2005 Barmer District. Directorate of Economics and Statistics, Rajasthan, Jaipur, p.123.

3. Anon. (2012) Agricultural Statistics Rajasthan, 2010-11. Directorate of Economics and Statistics, Rajasthan, Jaipur, p.105. 
4. Anon. (2014) Census of India 2011, Rajasthan, Series-09, Part XII-A District Census Handbook, Barmer. Village and Town Directory, Directorate of Census Operations, Rajasthan, Jaipur, p.1189.

5. Anon. (2016) District survey report, District Barmer, Rajasthan. Department of Mines and Geology, Govt. of Rajasthan, Jaipur, p. 54.

6. Anon. (2017b) Rajasthan Agricultural Statistics at a Glance, 2015-16. Commissionerate of Agriculture, Rajasthan, Jaipur, p. 228.

7. Anon. (2017c) Management plan for Desert National Park Wildlife Sanctuary, Plan Period 2017-2027. Rajasthan Forest Department, Jaipur, p.374.

8. Anon. (2017d) Industrial potential survey, Barmer district 2016-17. District Industries Centre, Barmer, p. 43.

9. Anon. (2017e) Industrial potential survey, Barmer district. MSME Technologies Development Centre-hand tools, Nagaur, p.25.

10. Anon. (2019) Agricultural Statistics Rajasthan, 2016-17. Directorate of Economics and Statistics, Dept. of Planning, Rajasthan, Jaipur, p.105.

11. BAIF (2012) Innovative framing system based livelihood model for desert region. BAIF Centre for Desert Region, Pune, p. 26.

12. Balak Ram (2004) Wasteland Updation Report of Barmer district, Rajasthan. Central Arid Zone Research Institute, Jodhpur, p. 37.

13. Beg, M. and Ahmad, S. (2015) Water resources management in arid and semi-arid regions of Rajasthan: A Case study. Proc. $8^{\text {th }}$ Int. Conf. on Recent advances in Civil Engg., Architecture and Env. Engg. for sustainable development.

14. BLMCL (2014) Environmental impact assessment and environmental management plan for capacity enhancement of Kapurdi lignite mine form 3.75 MTPA to 7.0 MTPA district Barmer, Rajasthan, Extent 3223.5110 ha. Barmer Lignite Mining Company LTD. p.375.

15. CAIRN (2018) EIA for proposed expansion of onshore oil and gas production from existing 300,000 barrels of oil per day (BOPD) to 400,000 BOPD and 165 Million standard feet per day (MMSCFD) to 750 MMSCFD from RJ-ON-90/1 Block, Barmer, Rajasthan. Final draft EIA Report, CAIRN India LTD. p.547.

16. CAZRI (1989) Integrated Natural \& Human Resource Appraisal, Barmer district. Central Arid Zone Research Institute, Jodhpur, p.179.

17. CAZRI (1999) Report on Land Use/Land Cover, Barmer District, Rajasthan, p. 19.

18. CGWB (2013) Ground water information, Barmer district, Rajasthan. Central Ground Water Board, Western Region, Jaipur, p.16.

19. District wise Mineral Report (Minor Minerals) year, 2017-18 Final xlsx. Deptt. of Mines and Geology, Udaipur,

20. EIL (2018). Environmental impact assessment study for proposed township of Rajasthan Refinery Project (RRP) at Sambhra, Barmer district, Rajasthan. Report No. B068-El-1421702, Feb. 2018. Engineers India Limited, New Delhi, p.219.

21. Kothari, V., Naidu, B., Sunder, V.R., Dolson, J., Burley, S.D., Whitley, Mohapatra, P. and Ananthakrishnan, B. (2015) Discovery of Petroleum System of Barmer Basin, India. CAIRN India LTD. p. 80.

22. Monsoon Report (2018) Water Resources Deptt., Govt. of Rajasthan, Jaipur, p.84

23. MSME (2011) Industrial potential survey, Barmer district. MSME Technology Development Centre, Nagaur, p.25.

24. Narmada Canal Project, Rajasthan.www.nationalwatermission.gov.in/ default/file/ waterwiki/ 14. Pdf. p.46

25. RSMML and WAPCOS (2014) EIA study of Giral lignite mine, district Barmer, Rajasthan, Final Report. Rajasthan State Mine and Minerals LTD. And WAPCOS, p.204.

26. Swain, M., Kalamkar, S.S. and Sharma, H. (2018) Pressurized irrigation network systems in India: Adoption, efficiency and dynamics. Allied Pub. Delhi, p.200. 